\title{
Planners as Leaders: Finding their Comfort Zone
}

\author{
Bonnie J. Johnson, PhD, AICP \\ Associate Professor, Urban Planning Program, \\ School of Public Affairs and Administration, University of Kansas \\ 1460 Jayhawk Blvd. \\ Snow Hall, Room 207 \\ Lawrence, KS 66045 \\ Phone 785-864-7147 \\ bojojohn@ku.edu
}

\begin{abstract}
Planners are expected to leave leadership to elected officials. Yet, they are often asked to do more. Should planners lead? This article examines how leadership is seen in the profession then outlines major theories of leadership and of planning. Using content analysis, those theories and descriptions of what planners do from professional planning codes of ethics from around the world are compared. Results indicate that new ways of thinking about leadership (group, servant, adaptive, authentic, spiritual, followership, and place-based) can help planners find leadership styles that fit their comfort zones better than old leadership definitions emphasizing heroic or coercive individuals. Results also show that shared/team based leadership is being overlooked by academia and practitioners.
\end{abstract}


In 2015, the major professional organization for planning in the United States, the American Planning Association (APA), issued the "Planning Office of the Future Task Force Report" (Horwedel et al., 2015) recommending, among other things, that planning offices "exercise leadership". Planners often find the role of leader disquieting, and the closest they get to leadership is perhaps "creating an environment for success and unleashing the power of others" (Riggs, 2015, p. 60) or "focusing attention on the vision" (Drinan, 2015, p. 3). Since the emergence of the profession in the early 1900's, city planners around the world have grappled with the complexities of public service planning, asking, how can seemingly apolitical, rational, neutral technicians also lead? (Brooks, 2002, Benveniste, 1989) How far can public sector planners stretch their discretion? (Forsythe, 1999, Lindquist et al., 2004) Major theories of "howto" plan are veritable treatises on how planners deal with having little to no power and that what power they do have has to be cobbled together through rationality, communication, facilitation, collaboration, and the opportune social movement (Brooks, 2002, Krumholz and Forester, 1990, Friedmann, 1973, Baum, 1983a, Fahmi et al., 2016, Allmendinger, 2009, Allmendinger, 2017, Flyvberg and Richardson, 2002, Hoch, 1994). City planners working directly for the public sector, or indirectly via contract, negotiate tough terrain if they try to be "technician/leaders," “facilitative leaders" (Forester, 2013), or "public servant/leaders". Schön asked of professionals (1983, p. 42), "Do you stay on the high ground where you can exercise technical rigor but have little social impact? Or do you descend to the swampy lowlands where you can make a difference but you must muddle through?” and perhaps lead?

How can planners pursue leadership when they have obligations as administrators, educators, facilitators, advisors, technicians, and are subject to the limitations associated with being unelected, public service providers? To answer this question, the article starts with a brief 
overview of the roots of the angst planners feel about leadership, planners' roles, and typical outlets for planners to lead. Next, strategies are presented for thinking about leadership and the evolution of leadership theories over time. Based on reviews of the literatures, tables are created listing the major theories of leadership and the major theories of "how-to" plan. Using content analysis, answers to the question, "what do planners do?" are taken from the codes of ethics of professional planning associations in: New Zealand, Norway, South Africa, Sri Lanka, the United Kingdom, United States, and the European Council of Urban Planners. Looking for evidence of leadership in planning, major leadership theories were compared to the type of leadership described in APA's "Planning Office of the Future Task Force Report" (Horwedel et al., 2015), the planning processes described in the major theories of "how-to" plan, and the planning processes in professional planning associations' codes of ethics from around the world.

The results of the analyses indicate that new ways of thinking about leadership can help planners find leadership styles that are a better fit for their roles than the old definition of leadership, which emphasized the heroic individual endowed with certain personality traits. Group leadership theories such as Complexity and Relational theories and procedural leadership called Substitutes for leadership seem to ring true for the APA "Planning Office of the Future Report" and for theories of "how-to" plan. Individual leadership theories match planning processes described in the international codes of ethics put together by practitioner organizations, particularly Servant, Adaptive/Empowering, and Authentic leadership. Surprisingly, the codes of ethics indicate practitioners should be Spiritual leaders as well.

By looking at how planning theorists and practitioners describe what planners do and matching those descriptions to leadership theories, it is apparent that there is a "comfort zone" for planners as leaders, but when they get out of that zone, they can find leadership roles 
untenable or too disquieting. The practitioners are leaning toward strategies individual planners can pursue for leadership while established planning theories are open to group leadership and substitutes for leadership. There are a few gaps where none of the established leadership theories seem to match what planners say they do. An even newer leadership theory called "place-based leadership" (Hambleton, 2015, Hambleton and Howard, 2013) appears to fill those gaps opening more doors for planners as leaders and playing into a strength of planning which is placemaking. By linking planning processes with leadership processes, leadership strategies planners can comfortably use in practice are revealed.

\section{Leadership and Planning}

In the beginning, the planning profession did not shy away from leadership as it borrowed from architecture the notion of a "master builder", mixed in engineering's "problem solver," and then drew on the moral high ground of social reformers (Baer, 1977, p. 672). In the 1910s, planners took on corrupt boss governments in cities ushering in planning commissions, comprehensive plans, and capital improvement budgets (Gerckens, 2000). Planners Lewis Mumford and Edmund Bacon were on the covers of Time magazine in 1938 and 1964 respectively. U.S. postage stamps, "plan for better cities," commemorated the $50^{\text {th }}$ anniversary of the American Institute of Planners in 1967. In 1977, Baer noted that after many years of struggle, U.S. planners were seeing their agendas become the public's agenda with courts upholding the legitimacy of planning. Yet, planners were in a malaise worried about rational processes subverted for ignoble causes and social reforms not yielding equitable results. People were questioning the role of government and whether experts really knew what they were doing (Farmer, 1994, Hollinger, 1994). Baer (1977, p. 676) notes, “While seeing themselves (planners) as the main gears in the urban machinery, other observers see them as the lubricants, alleviating 
the squeaks and lessening the friction of urban processes, but rarely acting as important cogs themselves." When people started questioning expertise and the inevitability of progress, planners became just another set of "fallible advisors who operate like everybody else, in a complex world where there are no 'answers' only diverse and indeterminate options" (Allmendinger, 2002, p. 88).

Adding to planners' discomfort with leadership is that the majority of them work directly for governments as public servants or indirectly as consultants hired by governments on contract. In the public sector, leadership by public servants is often associated with the "'pathologies' of public bureaucracies" (Getha-Taylor et al., 2011, p. 85). These pathologies include public servants overstepping the boundary between elected officials setting policy and public servants merely implementing policies, abusing their discretion, or going rogue and no one knowing it until it is too late (Fairholm, 2004). Discretion has its own distinctive pitfalls for public servants: "lack of accountability, manipulation, unpredictability, intrusiveness, and poor decision making" (Forsythe, 1999, p. 5). "Guerillas in the bureaucracy" (Needleman and Needleman, 1974) push the boundaries of their discretion, but as they seek to build trust with citizens and neighbors, they can lose trust with colleagues back at city hall and eventually burn out. Some see bureaucracies being buffeted by forces beyond their control making leadership a moot point (Van Wart, 2003). Abram (2004, p. 23) explains that it is one thing to outline a theoretical model where planners know when to switch their loyalties from elected officials to the public interest or to citizens and it is still yet another to practice planning in this "uncomfortable zone".

Today, planners are not seen as leaders. "(T)he feeling expressed by professionals is that planning generally has not received the media and public recognition deserved for its role in addressing urgent planning problems. The planning effort to rebuild the World Trade Center 
complex in New York . . . . is a case in point. While the architects, developers, Port Authority, and politicians are in the limelight, the planners involved in the project, like good stagehands, remain behind the wings and generally invisible. In a culture of hero worshipping, the planner remains a stoic antihero" (Myers and Banerjee, 2005, p. 122). Planning agencies are "rarely independent in their views, but serve those who have appointed them" with boards and commissions overseeing their work (Talvitie, 2012, p. 265). Fahmi et al. (2016, p. 310) note that planners often have to look for a "champion" from the outside for their ideas because "their power is not stronger than others". Also, as planners seek consensus and stakeholder participation, they undermine their very own claims to expertise and superior knowledge (Hoch, 1994, Flyvberg and Richardson, 2002).

\section{Roles of Planners}

A list of the many roles suggested for planners over the years, "master designer, rational analyst, social change agent, visionary, negotiator, monitor of communication flows, story teller, advocate, social interventionist, political strategist, specialist in comprehensiveness, customer service specialist, deal maker, designer of social institutions, group process facilitator" (Brooks, 2002, p. 136) does not include the role of leader. The roles merely hint at planners doing things that could include leadership like being a "master" of a skill, "making a deal," or having "vision". In 1977, Baer described roles for planners as "midwives" instead of "doctors" (1977). The most extensive work on the roles of planners divides them into three groups, technical, political, and a hybrid of the other two with the hybrid role being most common in the 1970s (Howe, 1980, Howe and Kaufman, 1979). An updating of the Howe and Kaufman study found more of today's planners identifying with the technical role over the political or hybrid roles (Lauria and Long, 2017). The technical planners find "power" in being known for their 
objectivity and neutrality, while the political planners are direct about their desire to influence policy. Even though the political planners seek to influence policy, they are "influencers" and not leaders, plus planners seem to be shying away from this role even more at the present time. Planners in Australia, Canada, Finland, France, Germany, the Netherlands, Norway, Scotland, Sweden, and the United Kingdom (Sager, 2009, Campbell and Marshall, 1999, Bäcklund et al., 2014, Mäntysalo et al., 2011, Waterhout et al., 2013, Jackson, 2009, Gunn and Vigar, 2012) are facing changing styles of public management called New Public Management which are placing them in more legal-procedural roles (Sager, 2009). Christensen (1985) explains that when there are clear goals and technical solutions to problems, planners can easily navigate political processes with their usual roles (regulator, analyst, advocate, mediator, experimenter, facilitator), but when there are unknowns for both goals and technology, then leadership is necessary. She explains that a "charismatic leader" is needed in those situations but that "(r)egrettably, charisma is hard to learn" (Christensen, 1985, p. 68), thus rendering planners (unless they happen to be charismatic) impotent.

Leading is often seen as entering the political realm and planners tend to shy away from politics. They shy away not only at the macro level involving elected officials, but also at the micro level involving internal, organizational politics (Gondim, 1988, Mayo, 1982, Baum, 1983b, Brooks, 2002). Innes and Gruber (2005) find planning styles (technical/bureaucratic, political influence, social movement, and collaborative) come into conflict due to different approaches to politics. Even the political influence style of planning described by Innes and Gruber (2005) is more about making sure resources are distributed to every jurisdiction rather than influencing policy or leading. The technical/bureaucratic style of planning "leads" by following established policies and legislative guidance, but then those planners are often 
disappointed when politicians do not rely on their studies or do not even allow for analysis in the first place. Collaborative planning's style is one where stakeholders learn together, share information, and hope leadership occurs. When leadership in planning styles is alluded too, such as with the social movement planning style, leadership comes from "champions" outside public agencies.

\section{Outlets for Leadership in Planning}

Planners can use their "discretionary space" to exercise leadership although that process is "slow and limited" (Forsythe, 1999, p. 12). Planners are often able to define the boundaries of their work and that dynamic is what Norman Krumholz used to find sources of power in Cleveland in the 1970s, along with using the media, networking, swapping favors, and having a talented staff (Krumholz and Forester, 1990). Progressive planners emphasize knowing power dynamics and communication techniques well enough to be prepared to counter obfuscations and misinformation. They also understand and use mediation, negotiation techniques, and group decision-making processes (Forester, 2013). Forsythe (1999, p. 12) maintains that these kinds of processes, which operate within the realm of discretion, may not be enough to "make truly effective changes" but could be boosted when combined with other strategies "such as work outside of government." Those "outsider" planners, such as those in academia and non-profit sectors, can help out by taking on leadership roles when public sector planners cannot (Karki, 2017, Innes and Gruber, 2005). Clients regularly hire planning consultants for their particular expertise and task them with leading communities in new directions. However, this leadership is contingent upon amenable clients and bounded by contracts.

Some say the only way for planners to legitimately pursue leadership roles is to run for elected office (Karki, 2017, Talvitie, 2012, Fahmi et al., 2016, Malizia, 2006). “As long as 
planners are taught to foster participation and be guided by what emerges from participatory processes, they may facilitate worthwhile development goals and objectives, but by definition they will never assume leadership positions" (Malizia, 2006, p. 408). Private sector planners must deliver for clients. Non-profit planners do not have much influence and public sector planners must beware of getting fired (Malizia, 2006). All the political skill in the world will not help planners lead, if they do not have political authority (Karki, 2017).

The $21^{\text {st }}$ century is calling on planners to be leaders. APA's "Planning Office of the Future Task Force Report" laid out five principles for effective planning. The second principle is "exercising leadership" and the first one is closely related, "thinking big" (Horwedel et al., 2015). Nelson (2006) argues for planners to be leaders and visionaries taking advantage of changing demographics and trends. Hurricane Katrina showcased why planners are needed as leaders (Olshansky, 2006). We know that sustainable development policies are more likely to move from policy to action if planning offices lead (Jepson, 2004). The lure of leadership and the potential to have a meaningful impact on societal problems draw students to planning (Myers and Banerjee, 2005, Brooks, 2002). The main accrediting body for schools of planning in the U.S., the Planning Accreditation Board, lists "leadership" as a required planning skill in their “Accreditation Standards and Criteria" (Planning Accreditation Board, 2017). There is much to do, such as, "lead local efforts to solve urban problems, lead the new dialogue about growth visions and futures, lead the building of collaborative partnerships, lead the partnerships fostering a new regionalism, lead international efforts for managing urban growth and development planning, and lead the campaign for urban sustainability" (Myers and Banerjee, 2005, p. 128). Innes (1997, p. 227) asserts, “(p)lanning has the potential in the $21^{\text {st }}$ century to be a leader among professions with public interest missions." 


\section{Leadership Theories}

To reach their potential as leaders, planners must figure out how to successfully turn their discretionary space, which is presently an "uncomfortable zone" (Abram, 2004, p. 23), into their "comfort zone". A greater understanding of leadership in its many forms and how power relates to leadership can assist planners. Leaders are "persons who, by word and/or personal example, markedly influence the behavior, thoughts, and/or feelings of a significant number of their fellow human beings (here termed followers or audience members)" (Gardner, 1995, pp. 8-9). This is perhaps what comes to mind when one hears the words "leader" and "leadership." However, the very definition of "leadership" has evolved over time and has become more process oriented including organizational and social skills (Hosking, 1988). Table 1 shows the progression in leadership processes from no leaders/procedures, to groups of leaders, to single leaders. Leadership is now defined in more expansive terms as "a phenomenon focused on vision, challenge, collaboration, process, and product” (Sorenson et al., 2011, p. 33).

$<<$ Table 1- About Here>>

Leadership is no longer just about a leader's personal traits. Northhouse (2016) citing Rost (1991) takes us from the 1900s to today. From 1900 - 1929, leadership was the ability to get others to do what the leader wanted them to do, usually through power and domination, exemplified by Directive leadership (coercion) and Transactional leadership (using rewards) (see Table 1). In the 1930s, leadership was defined as influence, not domination, facilitated by the leader's personality traits matching those of the group. Leadership as involving "groups" dominated the 1940s - 1960s with the emergence of persuasion as a tactic, defining shared goals, and leadership meaning group effectiveness. The 1970s brought a shift in thinking from focusing 
on groups to focusing on organizations and leadership became a reciprocal process where people's motives and values are mobilized along with resources to accomplish a leader's and followers' mutual goals. Leadership theories flourished in the 1980s and saw the return of leadership as getting others to do what the leader wants, leadership as non-coercive influence, leaders possessing certain traits, but then a new variant emerges, leadership as transformation. Transformational/charismatic leadership emphasizes that leaders and their followers evolve together with leaders and followers becoming high achievers. Moving into the $21^{\text {st }}$ century, leadership is defined as a "process" and there are multiple processes. A few of these new processes are Authentic leadership (being transparent and using one's own ethical behavior as exemplar), Spiritual leadership (creating a sense of meaning in people's lives), Servant leadership (attending to the needs of followers), and Adaptive/empowering leadership (emphasizing learning and self-development) (see Table 1 for details).

Leadership is no longer seen as simply being a leader directing followers, but has shifted to an emphasis on followers and on systems of leadership or shared leadership. For many years, followers and their actions were simply seen as the outcomes of leadership. Changing the leadership lens to focus on followers highlights that leaders depend on followers and they can influence each other's effectiveness (see Followership and Shared/team leadership in Table 1). The characteristics of followers affect who emerges as leaders (Avolio et al., 2009). Adding in the notion of Shared leadership points out that quality followers are ones who know when they should lead and when they should follow and are skilled at both (Pearce and Conger, 2003). There are even times when no leader is needed and Substitutes for leadership, such as, professional norms, routines, brainstorming techniques, and group-decision making processes, suffice (Pearce and Conger, 2003, Avolio et al., 2009). 
Leadership processes with many leaders working together do not rely on the traits or characteristics of one top-down person. It manifests at the group-level occurring throughout the organization and rooted in social interactions and mutual learning (Avolio et al., 2009, Uhl-Bien et al., 2007, Fletcher and Käufer, 2003). Other variations of Shared leadership are Team leadership (small groups lead), Relational leadership (socially constructed relationships), and Complexity leadership (interdependent agents). Quick (2017) found planning processes can combine collective leadership and collective impact.

In addition to process, leadership can be viewed as "power." Power and leadership are linked because as people influence others, they are seen as wielding power. In leadership studies, power as a variable has not garnered much attention (Northhouse, 2016). However, there is a framework for categorizing the types and bases of leaders' power. There are two types of power, power in a person's position or rank and personal power due to the person being a good role model, knowledgeable, and knowable. The bases of power are: referent (being likable), expert (being competent), legitimate (having status), reward (being able to give recompense), coercive (being able to penalize others), and information (having knowledge others want) (Northhouse, 2016, French and Raven, 1959, Raven, 1965, French and Raven, 1962, Kotter, 1990). It is the fear of information and expert power being in the hands of public servants that leads the public and elected officials to insist on accountability and transparency (Brehm and Gates, 1997). Today, the Internet greatly levels the information playing field giving followers more power (Northhouse, 2016). As leadership theories evolved over time, the notion of "power with" instead of "power over" emerged, and, thus, leaders do not wield power alone, the leaders and followers have power together (Follett, 1926/1987, Burns, 1978). The shift to "power with" highlights the need to understand power and be aware of judgements being impaired or 
dominated by a leader's own or a group's viewpoint (Gordon, 2011, Barabas, 2004, Janis, 1982). A critique of leadership research is that it does not confront the problems associated with power (Gordon, 2011). Similarly, theories of "how-to" plan struggle with notions of power and often direct planners toward indirect sources of power.

\section{Methodology}

The primary question for this study is "Should planners lead?" which planning academics and practitioners have answered as, "Yes, well, sort of, there is a desire to do so, we probably should, but it is difficult, contingent, limited, problematic, and uncomfortable." The next question is, "Are there more viable routes to leadership for planners?" To answer that question, literature reviews and content analyses are used. The major theories of leadership are compared to how exercising leadership is described in APA's "Planning Office of the Future Task Force Report” (Horwedel et al., 2015), the planning processes (keywords/concepts) described in the major theories of "how-to" plan and the descriptions of planning processes (themes) contained in the codes of ethics from professional planning associations around the world.

\section{Leadership Theories}

The leadership theories in Table 1 were gathered from texts and articles summarizing and compiling established theories of leadership (Bryman et al., 2011, Avolio et al., 2009, Pearce et al., 2003, Northhouse, 2016). Theories common across the texts and articles were included and then definitions and lists of processes were based on those sources and supplemented by the leadership literature specific to each theory.

\section{Planning Theories}

The type of planning theories included in Table 2 were chosen based on Faludi's (1973) "theory of planning" focus on procedural theories of "how to" plan, supplemented by Yiftachel's 
(1989) search for “What is a good planning process?”, Brook’s (2002) theories centered on helping practitioners decide what to do when, and Allmendinger's (2017) indigenous planning theory which are theories that are "planning-specific". The theories in Table 2 are recognizable as planning theories, perhaps with origins from other disciplines, but theories which planners have regularly espoused over time and now are presented, not as single, unified theories, but choices that practicing planners have as options depending on time, place, and politics (Brooks, 2002). For Table 2, theories from Allmendinger and Brooks are included and then definitions are augmented by sources specific to or using each theory. The leadership theories and planning theories are compared looking for matches in keywords and concepts described in the processes. This is the same procedure followed when matching the leadership processes described in the APA's "Planning Office of the Future Task Force Report" with leadership theories and their processes.

$<<$ Table 2 - About Here $>$

\section{Codes of Ethics}

Codes of ethics from professional planning organizations are useful distillations of what practitioners think are "the norms that ought to govern professional behavior" (Frankel, 1989, p. 109). They outline what a profession sees as important in terms of knowledge, techniques, or what members "ought" to do and be like (Frankel, 1989, Davis, 2003, Freckelton, 1996) what are here called "processes". Finding codes of ethics started with the list of 82 national planning associations from Algeria to Zimbabwe contained on the Royal Town Planning Institute's webpage (Royal Town Planning Institute, 2011) and, when that webpage was no longer active, the membership lists from the Global Planners Network (Global Planners Network, 2017) and from the European Council of Spatial Planners (European Council of Spatial Planners / Conseil 
Européen des Urbanistes, 2017b) were used. From those lists and using Google Translate when needed, each association's website was explored looking for a "code of ethics" or "code of conduct". Not all of them had codes of ethics on their websites. After the search, seven codes were selected from professional planning organizations in different parts of the world: New Zealand (New Zealand Planning Institute, 2017), Norway (Forum for Kommunal Planlegging, 2017), South Africa (South African Planning Institute, 2017), Sri Lanka (Institute of Town Planners Sri Lanka, 2017), United Kingdom (Royal Town Planning Institute, 2017), United States (American Planning Association, 2017), and the European Council of Urban Planners (European Council of Spatial Planners / Conseil Européen des Urbanistes, 2017a). All of these codes were in English on their websites. The codes were read looking for processes or "what do planners do?" particularly in relation to the public. Each process was listed only once and then matched to keywords, concepts, or themes from the leadership theories' processes.

\section{Results}

How planning leadership is described in APA's "Planning Office of the Future Task Force Report" (Horwedel et al., 2015), theories of "how-to" plan, and the descriptions of what planners do from professional planning organizations' codes of ethics were compared with the theories of leadership and their processes contained in Table 1.

\section{The Planning Office of the Future}

The "Planning Office of the Future Task Force Report" describes how planners should pursue "Exercising Leadership" by listing three strategies and seven actions. The three strategies are to: "get close to decision-makers, exercise different kinds of community leadership, and address emerging issues and trends" (Horwedel et al., 2015, p. 18). The actions are to: "define the planning agency's purpose and scope, develop informal networks, educate elected officials 
and citizens, build consensus with other agencies, communicate through various news media, identify and assess trends as they emerge, and educate the community about issues and trends" (Horwedel et al., 2015, p. 18). Table 3 shows how the report's list of how to exercise leadership compares to the theories of leadership. Seven out of the 10 planning processes related to the definition and leadership processes contained in Complexity leadership theory (dynamic networks). One of the other three most closely resembles Relational leadership (socially constructed relationships) and one, "Exercise different kinds of community leadership" does not match any of the theories. Another one, "Define the planning agency's purpose and scope" aligns with the leadership theory of Substitutes for leadership which is simply procedures with no designated person or group as leaders. Setting the procedure in motion is intended to structure leadership or power. Both Complexity and Relational theories are Group theories of leadership, which seek "power with" others. This report's description of leadership suggests planners rely on Groups or procedural Substitutes for leadership.

$<<$ Table 3 - About Here >>

\section{Theories of "How-to" Plan}

The descriptions of planning processes from each of the planning theories in Table 2 were compared to the leadership theory definitions and processes in Table 1 and the results are shown in Table 4. There are 10 planning theories and they fall into 5 leadership theory categories. Of the five leadership theories matched with planning theories, two are Group leadership, one is a Substitute for leadership (no leaders), and two are leadership by Individuals.

Of the leadership theories in Table 4, the most commonly occurring keywords from the planning theories are matched with Adaptive/Empowering leadership (learning and self-development, 
Individual) (5 matches), then Complexity (dynamic networks, Group) (3 matches), Substitutes (procedures as leaders) (2 matches), Relational (socially constructed relationships, Group) (2 matches), and Authentic (leader is example, Individual) (1 match). The planning theories are showing an almost even split between Group leadership and Individual leadership theories. The Individual theories (Adaptive/Empowering and Authentic) are exercising power through empowering others or power through example. The Complexity and Relational theories find "power with" others.

<<Table 4 - About Here >

\section{Codes of Ethics}

For the codes of ethics, each one was read looking for phrases that described what planners do (processes), then themes common to the codes of ethics and the various descriptions of leadership theories were found. In the American Institute of Certified Planners' (AICP) code of ethics from the United States, processes most often coincided with Authentic leadership (leader is example, Individual) (5 matches) and Adaptive/Empowering leadership (learning and self-development, Individual) (5 matches) (see Table 5). The next most common matches between planning processes in the codes and leadership theories were Servant (attending to the needs of followers, Individual) (4 matches) and Complexity (dynamic networks, Group) (4 matches) then Spiritual (sense-making, Individual) and Followership (followers can make or break a leader, Individual) at three matches each. Five of the leadership theories are applicable to Individuals or Followers and one of the theories is a Group theory (Complexity), where there are many leaders acting together. In the AICP code, there is more reliance on Individual theories of leadership and less reliance on groups. 
$<<$ Table 5 - About Here >>

For the professional planning organization in the United Kingdom, the Royal Town Planning Institute, their code of ethics' planning processes most often coincided with Servant (attending to the needs of followers, Individual) and Authentic leadership (leader is example, Individual) (3 matches each) and then Spiritual (sense-making, Individual) (2 matches) and Adaptive/Empowering (learning and self-development, Individual) once (see Table 6). All of these leadership theories are Individual leadership theories.

$<<$ Table 6 - About Here >>

In New Zealand the professional planning organization is the New Zealand Planning Institute. Their code of ethics' planning processes most often coincided with Authentic leadership (leader is example, Individual) (4 matches) then Complexity (dynamic networks, Group) (2 matches), Servant (attending to the needs of followers, Individual) (2 matches), Adaptive/empowering (learning and self-development, Individual) once, and Followership (followers can make or break a leader, Individual) once (see Table 7). All of these leadership theories are for Individuals or Followers except for one, Complexity, a Group theory. $<<$ Table 7 - About Here >>

In the South African Planning Institute's code of ethics, what planners do most often coincided with Authentic leadership (leader is example, Individual) (5 matches) then Followership (followers can make or break a leader, Individual) (4 matches), Spiritual (sensemaking, Individual) (3 matches), and Servant (attending to the needs of followers, Individual), Adaptive/empowering (learning and self-development, Individual), Complexity leadership 
(dynamic networks, Group) theories each occurred one time (see Table 8). Five of the leadership theories are applicable to Individuals or Followers and one of the theories is a Group theory (Complexity).

$<<$ Table 8 - About Here >>

The Charter of Professional Conduct for the European Council of Spatial Planners / Conseil Européen des Urbanistes is short, although it refers to other parts of the charter, which would add more detail, and contains planning processes that can be matched to four different leadership theories. Two planning processes can be matched with Authentic leadership (leader is example, Individual) as well as two for Spiritual leadership (sense-making, Individual). Adaptive/empowering (learning and self-development, Individual) and Complexity leadership (dynamic networks, Group) are matched one each. Three of the four theories apply to Individuals and one (Complexity) to Groups.

$<<$ Table 9 - About Here >

The Code of Conduct for the Institute of Town Planners, Sri Lanka has planning processes that match with four different leadership theories with one match each, Servant (attending to the needs of followers, Individual), Authentic (leader is example, Individual), Spiritual (sense-making, Individual), and Adaptive/empowering (learning and self-development, Individual) (see Table 10). These are all theories of Individual leadership.

$<<$ Table 10 - About Here > 
Norway's Forum for Municipal Planning Ethical Platform has planning processes that match with six leadership theories. Those theories and their number of matches from greatest to lowest are: Complexity (dynamic networks, Group) (4 matches), Authentic (leader is example, Individual) (3 matches), Followership (followers can make or break a leader, Individual) (3 matches), Servant (attending to the needs of followers, Individual) (2 matches), Spiritual (sensemaking, Individual) (2 matches), and Adaptive/empowering (2 matches). All are Individual forms of leadership except for Complexity, which is a Group form of leadership.

$<<$ Table $11-$ About Here >

\section{Discussion}

New ways of thinking about leadership give planners more tools to use (Substitutes for leadership, Followership, Group leadership, specific Individual leadership theories), other than their charisma, and they provide a roadmap for planners to find their leadership "comfort zone". As they described how planners grapple with their discretion, Forsyth (1999) and Abram (2004), in particular, noted how planners operate from an "uncomfortable zone". Matching what planners do, or would like to do, with leadership theories shows where planners can find their leadership "comfort zone" and see what other tools they have (see Table 12). Across all the sources of planning processes used in this study, APA's "Planning Office of the Future Task Force Report", major theories of "how to" plan, and codes of ethics from professional planning associations internationally, there is a preference for one of the Group leadership theories Complexity leadership. Complexity leadership relies on "power with" but also information flows and dynamic networks. Across planning theories and codes of ethics two Individual 
leadership theories were found, Adaptive/empowering and Authentic leaderships. These two theories focus on being open, mutual learning, and empowering others. They also speak to being authentic, but not necessarily having to be charismatic.

<<Table 12 - About Here〉>

The codes of ethics can perhaps give insights into what practitioners see as their comfort zone for leadership. Planning processes from the codes of ethics matched five different leadership theories: Servant, Adaptive/empowering, Spiritual, Authentic, and Followership. It is interesting to note that neither the APA report nor the planning theories noticed Servant leadership, but the practitioners did. Servant leadership fits well with the public servant role many planners play. This leadership theory turns what can seem like a limiting, servile role into an actionable, leadership role involving healing, empathy, community building, and inspiring commitment.

Just as the Servant leadership theory turns what could be a limiting role into an action role, the Followership leadership theory also turns the planner's role of "follower" into a role requiring skill and possessing agency. Followers have to know when to lead and when to follow and they can choose how to follow (or not).

Another role that matched codes but not the APA report or planning theories is the Spiritual leadership role. This is an area where planners might be stretching their discretion and getting into an "uncomfortable zone", but here are professional planning organizations asking practitioners to take the risk. The Spiritual leadership role is about creating meaning in people's lives and that closely aligns with planning goals related to quality of life and sense of 
community. Planners have carved out these issue areas as being important to their work and they inherently place planners in a challenging, Spiritual leadership role.

Three of the codes of ethics from the United States, New Zealand, and South Africa (Tables 5, 7, and 8) listed planning processes that could not be matched with any of the wellestablished leadership theories from Table 1. An anonymous reviewer of an earlier version of this article noted that a new theory of leadership, place-based leadership, would be amenable to what planners do. Place-based leaders are "those exercising decision-making power (who) have a concern for the communities living in a particular 'place"' (Hambleton and Howard, 2013, p. 54). Place-based leadership "prizes respect for the feelings and attitudes of others as well as a strong commitment to collaboration" (Hambleton and Howard, 2013, p. 55). This theory is a Group leadership theory, but is akin to the Individual theory of Spiritual leadership. They are both about sense-making but place-based leadership roots that sense-making in particular places, cultures, and landscapes. The planning processes that could not be matched to established planning theories all picked up on themes of the use of natural resources, development of people in the country, protecting the environment, and the integrity and heritage of natural and built environments.

The uncomfortable zone for planners clearly consists of the Individual leadership theories requiring particular personality traits, charisma, status, the ability to bestow rewards, and the ability to coerce (Transformation/charismatic, Leader-member exchange, Transactional, and Directive). However, another uncomfortable area is the Group theory of Shared/team leadership. None of the sources of planning processes studied here matched with the Shared/team leadership theory. This could be an area for planners to explore and bring into their role definitions. They are not taking advantage of a leadership strategy of small group empowerment. The codes of 
ethics are also not taking advantage of Group leadership theories (Complexity and Relational) or Substitutes for leadership even though the "Planning Office of the Future" and planning theories mention them.

Planning theory and planning educators can learn from practitioners that Individual leadership theories are a part of planning practice. When "power with" or group processes are not working for planners, they can have agency in the form of Individual leadership theories: Followership, Servant, Adaptive/empowering, Spiritual, and Authentic. Practitioners should think back to their planning theory and remember they have Group leadership theories they can rely on: Complexity and Relational. They also should gain confidence that some of their processes are actually leadership strategies called Substitutes for leadership. APA's "Planning Office of the Future Report" focuses on Group theories but misses out on useful Individual leadership strategies. A new theory, place-based leadership, is well within the realm of what planners do and it has the potential to make Spiritual leadership not as risky as or as difficult as it might appear on its face.

\section{Finding their Comfort Zone}

Perhaps those early rational, positivist planners flew too close to the sun and they had to be brought down to earth. However, does that mean planners cannot and should not be leaders? The definition of leadership has changed. It used to be based largely on the personal traits of individual leaders. It is now defined as "a phenomenon focused on vision, challenge, collaboration, process, and product" (Sorenson et al., 2011, p. 33). That definition sounds an awful lot like what planners do.

Group leadership, Substitutes for leadership, and well-chosen Individual leadership theories take us out of the heroic, personality or coercion driven kinds of leadership that may 
have proven too uncomfortable for planners. By embracing Group leadership and Substitutes for leadership, being skilled Followers, branching out into Shared/team leadership, and paying attention to codes of ethics emphasizing Authentic, Adaptive/empowering, Spiritual, Servant, and place-based leadership processes, practicing planners can take action. Planners can be effective leaders, they just need to find their "place" or comfort zone. 


\section{References}

Abram, S. (2004), "Personality and Professionalism in a Norwegian District Council", Planning Theory, Vol. 3 No. 1, pp. 21-40.

Allmendinger, P. (2002), "Towards a Post-positivist Typology of Planning Theory", Planning Theory, Vol. 1 No. 1, pp. 77-99.

Allmendinger, P. (2009), Planning Theory, 2nd ed., Palgrave Macmillan, Hampshire, UK.

Allmendinger, P. (2017), Planning Theory, 3rd ed., Palgrave, London.

American Planning Association. (2017), "AICP Code of Ethics and Professional Conduct", available at: https://www.planning.org/ethics/ethicscode/ (accessed August 27 2017).

Avolio, B.J., Walumbwa, F.O. and Weber, T.J. (2009), "Leadership: Current Theories, Research, and Future Directions", Annual Review of Psychology, Vol. 60 No. 1, pp. 421-49.

Bäcklund, P., Kallio, K.P. and Häkli, J. (2014), "Residents, customers or citizens? Tracing the idea of youthful participation in the context of administrative reforms in Finnish public administration", Planning Theory \& Practice, Vol. 15 No. 3, pp. 311-27.

Baer, W.C. (1977), "Urban Planners: Doctors or Midwives?", Public Administration Review, Vol. 37 No. 6, pp. 671-78.

Barabas, J. (2004), "How Deliberation Affects Policy Opinions", American Political Science Review, Vol. 98 No. 4, pp. 687-701.

Baum, H.S. (1983a), Planners and Public Expectations, Schenkman Publishing Company, Inc., Cambridge, MA.

Baum, H.S. (1983b), "Politics and Ambivalence in Planners' Practice", Journal of Planning Education and Research, Vol. 3 No. 1, pp. 13-22.

Benveniste, G. (1989), Mastering the Politics of Planning: Crafting Credible Plans and Policies, Jossey-Bass, San Francisco.

Brehm, J. and Gates, S. (1997), Working, Shirking, and Sabotage: Bureaucratic Response to a Democratic Public, University of Michigan Press, Ann Arbor, MI. 
Brooks, M.P. (2002), Planning Theory for Practitioners, Planners Press, Chicago, IL.

Bryman, A., Collinson, D., Grint, K., Jackson, B. and Uhl-Bien, M. (2011), "The SAGE Handbook of Leadership", in, Sage, Thousand Oaks, CA.

Burns, J.M. (1978), Leadership, Harper \& Row, New York.

Campbell, H. and Marshall, R. (1999), "Ethical Frameworks and Planning Theory", International Journal of Urban and Regional Research, Vol. 23 No. 3, pp. 464-78.

Christensen, K.S. (1985), "Coping with Uncertainty in Planning", Journal of the American Planning Association, Vol. 51 No. 1, pp. 63-73.

Davis, M. (2003), "What can we learn by looking for the first code of professional ethics?", Theoretical Medicine and Bioethics, Vol. 24 No. 5, pp. 433-54.

Drinan, J.M. (2015), "Life, Water, and the Pursuit of Leadership", Planning, Vol. 81 No. 7, pp. 3.

European Council of Spatial Planners / Conseil Européen des Urbanistes. (2017a), "Draft Principles of Professional Conduct", available at: http://www.ectpceu.eu/images/stories/PDFdocs/DRAFT\%20REVISED\%20PRINCIPLES\%200F\%20PROFESSIONAL\%20COND UCT\%202013.pdf (accessed August 27 2017).

European Council of Spatial Planners / Conseil Européen des Urbanistes. (2017b), "Members", available at: http://www.ectp-ceu.eu/index.php/en/members/full-members/vrp-2 (accessed August 27 2017).

Fahmi, F.Z., Prawira, M.I., Hudalah, D. and Firman, T. (2016), "Leadership and collaborative planning: The case of Surakarta, Indonesia", Planning Theory, Vol. 15 No. 3, pp. 294315.

Fairholm, M.R. (2004), "Different Perspectives on the Practice of Leadership", Public Administration Review, Vol. 64 No. 5, pp. 577-90.

Faludi, A. (1973), Planning Theory, Pergamon Press, Oxford. 
Farmer, D.J. (1994), The Language of Public Administration: Bureaucracy, Modernity, and Postmodernity, University of Alabama Press, Tuscaloosa, AL.

Fletcher, J.K. and Käufer, K. (2003), "Shared Leadership: Paradox and Possibility", in Pearce, C.L. and Cooper, J.A. (Eds.), Shared Leadership: Reframing the Hows and Whys of Leadership, Sage, Thousand Oaks, CA, pp. 21-47.

Flyvberg, B. and Richardson, T. (2002), "Planning and Foucault", in Allmendinger, P. and Tewdwr-Jones, M. (Eds.), Planning Futures: New Directions for Planning Theory, Routledge, London, pp. 44-62.

Follett, M.P. (1926/1987), "The Giving of Orders", in Shafritz, J.M. and Hyde, A.C. (Eds.), Classics of Public Administration, Second ed., Brooks/Cole Publishing Co., Pacific Grove, CA, pp. 65-74.

Forester, J. (2013), Planning in the Face of Conflict, American Planning Association Planners Press, Chicago.

Forsythe, A. (1999), "Administrative Discretion and Urban and Regional Planners' Values", Journal of Planning Literature, Vol. 14 No. 1, pp. 5-15.

Forum for Kommunal Planlegging. (2017), "Etisk-Plattform - - Engelsk", available at: http://www.ks.no/globalassets/blokker-til-hvert-fagomrade/samfunn-ogdemokrati/forum-for-kommunal-planlegging/etisk-plattform-fkp-forslag-17-08-2016--engelsk.pdf (accessed August 27 2017).

Frankel, M.S. (1989), "Professional Codes: Why, How, and with What Impact?", Journal of Business Ethics, Vol. 8 No. 2/3, pp. 109-15.

Freckelton, I. (1996), "Enforcement of Ethics", in Coady, M. and Bloch, S. (Eds.), Codes of Ethics and the Professions, Melbourne University Press, Melbourne, Australia, pp. 13065 .

French, J.R., Jr. and Raven, B. (1962), "The Bases of Social Power", in Cartwright, D. (Ed.) Group Dynamics: Research and Theory, Harper \& Row, New York.

French, J.R., Jr. and Raven, B.H. (1959), "The Bases of Social Power", in Cartwright, D. (Ed.) Studies in Social Power, Institutue for Social Research, Ann Arbor, MI.

Friedmann, J. (1973), Retracking America, Anchor Press/Doubleday, Garden City, NY. 
Gardner, H. (1995), Leading Minds: An Anatomy of Leadership, BasicBooks, New York.

Gerckens, L.C. (2000), "Ten Successes that Shaped the 20th Century American City", Planning Commissioners Journal, Vol. 38 No. 1, pp. 3-11.

Getha-Taylor, H., Holmes, M.H., Jacobson, W.S., Morse, R.S. and Sowa, J.E. (2011), "Focusing the Public Leadership Lens: Research Propositions and Questions in the Minnowbrook Tradition", Journal of Public Administration Research and Theory: J-PART, Vol. 21, pp. i83-i97.

Global Planners Network. (2017), "Membership", available at: http://www.globalplannersnetwork.org/membership/ (accessed August 27 2017).

Gondim, L.M. (1988), "Planning Practice within Public Bureaucracy: A New Perspective on Roles of Planners", Journal of Planning Education and Research, Vol. 7 No. 3, pp. 16372.

Gordon, R. (2011), "Leadership and Power", in Bryman, A., Collinson, D., Grint, K., Jackson, B. and Uhl-Bien, M. (Eds.), The Safe Handbook of Leadership, Sage, Los Angeles.

Gunn, S. and Vigar, G. (2012), "Reform processes and discretionary acting space in English planning practice, 1997-2010", TPR: Town Planning Review, Vol. 83 No. 5, pp. 533-52.

Hambleton, R. (2015), Leading the Inclusive City: Place-Based Innovation for a Bounded Planet, Policy Press, Bristol, UK.

Hambleton, R. and Howard, J. (2013), "Place-based Leadership and Public Service Innovation", Local Government Studies, Vol. 39 No. 1, pp. 47-70.

Hoch, C. (1994), What Planners Do: Power, Politics, and Persuasion, Planners Press, Chicago, IL.

Hollinger, R. (1994), Postmodernism and the Social Sciences: A Thematic Approach, Sage, Thousand Oaks, CA.

Horwedel, J., Costa, F., Lindsey, L., Poppel, K., Silver, M., Stoll, G. and Zelinka, A. (2015), "Planning Office of the Future Task Force Report", in, American Planning Association, Chicago, IL. 
Hosking, D.M. (1988), "Organizing, Leadership and Skilful Process", Journal of Management Studies, Vol. 25 No. 2, pp. 147-66.

Howe, E. (1980), "Role Choices of Urban Planners", Journal of the American Planning Association, Vol. 46 No. 4, pp. 398-409.

Howe, E. and Kaufman, J. (1979), "The Ethics of Contemporary American Planners", Journal of the American Planning Association, Vol. 45 No. 3, pp. 243-55.

Innes, J.E. (1997), "The Planners' Century", Journal of Planning Education and Research, Vol. 16 No. 3, pp. 227-28.

Innes, J.E. and Gruber, J. (2005), "Planning Styles in Conflict: The Metropolitan Transportation Commission", Journal of the American Planning Association, Vol. 71 No. 2, pp. 177-88.

Institute of Town Planners Sri Lanka. (2017), "Code of Conduct", available at: http://www.itpsl.1k/code_of_conduct/ (accessed August 27 2017).

Jackson, J. (2009), "Neo-liberal or Third Way? What Planners from Glasgow, Melbourne and Toronto Say", Urban Policy and Research, Vol. 27 No. 4, pp. 397-417.

Janis, I.L. (1982), Groupthink, 2nd ed., Houghton Mifflin Company, Boston, MA.

Jepson, E.J., Jr. (2004), "Human Nature and Sustainable Development: A Strategic Challenge for Planners", Journal of Planning Literature, Vol. 19 No. 1, pp. 3-15.

Karki, T.K. (2017), "Should planners join politics? Would that help them make better cities?", Planning Theory, Vol. 16 No. 2, pp. 186-202.

Kotter, J.P. (1990), A Force for Change: How Leadership Differes from Management, Free Press, New York.

Krumholz, N. and Forester, J. (1990), Making Equity Planning Work: Leadership in the Public Sector, Temple University Press, Philadelphia, PA.

Lauria, M. and Long, M. (2017), "Planning Experience and Planners' Ethics", Journal of the American Planning Association, Vol. 83 No. 2, pp. 202-20. 
Lindquist, S.A., Rainey, H.G. and Jarry, E. (2004), "Eternal Disquiet: Discretionary Action by Unelected Officials in the Administrative State", in Annual Meeting of the American Political Science Association, Chicago, IL.

Malizia, E. (2006), "Comment on "Planning Leadership in a New Era"", Journal of the American Planning Association, Vol. 72 No. 4, pp. 407-09.

Mäntysalo, R., Saglie, I.-L. and Cars, G. (2011), "Between Input Legitimacy and Output Efficiency: Defensive Routines and Agonistic Reflectivity in Nordic Land-Use Planning", European Planning Studies, Vol. 19 No. 12, pp. 2109-26.

Mayo, J.M. (1982), "Sources of Job Dissatisfaction: Ideals Versus Realities in Planning", Journal of the American Planning Association, Vol. 48 No. 4, pp. 481-95.

Myers, D. and Banerjee, T. (2005), "Toward Greater Heights for Planning: Reconciling the Differences between Profession, Practice, and Academic Field", Journal of the American Planning Association, Vol. 71 No. 2, pp. 121-29.

Needleman, M.L. and Needleman, C.E. (1974), Guerrillas in the Bureaucracy: The Community Planning Experiment in the United States, John Wiley \& Sons, New York City, NY.

Nelson, A.C. (2006), "Leadership in a New Era", Journal of the American Planning Association, Vol. 72 No. 4, pp. 393-407.

New Zealand Planning Institute. (2017), "Code of Ethics", available at: https://www.planning.org.nz/Category?Action=View\&Category_id=613 (accessed August 27 2017).

Northhouse, P.G. (2016), Leadership: Theory and Practice, Seventh ed., Sage, Thousand Oaks, CA.

Olshansky, R.B. (2006), "Planning After Hurricane Katrina", Journal of the American Planning Association, Vol. 72 No. 2, pp. 147-53.

Pearce, C.L. and Conger, J.A. (2003), "All Those Years Ago: The Historical Underpinnings of Shared Leadership", in Pearce, C.L. and Conger, J.A. (Eds.), Shared Leadership: Reframing the Hows and Whys of Leadership, Sage, Thousand Oaks, CA, pp. 1-18.

Pearce, C.L., Sims, H.P., Cox, J.F., Ball, G., Schnell, E., Smith, K.A. and Trevino, L. (2003), "Transactors, transformers and beyond: A multi-method development of a theoretical 
typology of leadership", Journal of Management Development, Vol. 22 No. 4, pp. 273307.

Planning Accreditation Board. (2017), "PAB Accreditation Standards and Criteria", in, Planning Accreditation Board, Chicago, IL.

Quick, K.S. (2017), "Locating and building collective leadership and impact", Leadership, Vol. 13 No. 4, pp. 445-71.

Raven, B.H. (1965), "Social Influence and Power", in Steiner, I.D. and Fishbein, M. (Eds.), Current Studies in Social Psychology, Holt, Rinehar, \& Winston, New York.

Riggs, W. (2015), "Lessons in Leading", Planning, Vol. 81 No. 2, pp. 60.

Rost, J.C. (1991), Leadership for the Twenty-first Century, Praeger, New York.

Royal Town Planning Institute. (2011), "Planning Organisations World-Wide", available at: http://www.rtpi.org.uk/item/1063/ (accessed February 3 2011).

Royal Town Planning Institute. (2017), "Professional Standards", available at: http://www.rtpi.org.uk/membership/professional-standards/ (accessed August 27 2017).

Sager, T. (2009), "Planners' Role: Torn between Dialogical Ideals and Neo-liberal Realities", European Planning Studies, Vol. 17 No. 1, pp. 65-84.

Sorenson, G., Goethals, G.R. and Haber, P. (2011), "The Enduring and Elusive Quest for a General Theory of Leadership: Initial Efforts and New Horizons", in Bryman, A., Collinson, D., Grint, K., Jackson, B. and Uhl-Bien, M. (Eds.), The Sage Handbook of Leadership, Sage, Los Angeles, pp. 29-36.

South African Planning Institute. (2017), "Code of Conduct", available at: http://sapi.org.za/wpcontent/uploads/2017/08/The-South-African-Planning-Institute-Code-of-Conduct-July2005.pdf (accessed August 27 2017).

Talvitie, A. (2012), "The problem of trust in planning", Planning Theory, Vol. 11 No. 3, pp. 25778.

Uhl-Bien, M., Marion, R. and McKelvey, B. (2007), "Complexity Leadership Theory: Shifting leadership from the industrial age to the knowledge era", The Leadership Quarterly, Vol. 18 No. 4, pp. 298-318. 
Van Wart, M. (2003), "Public-Sector Leadership Theory: An Assessment", Public Administration Review, Vol. 63 No. 2, pp. 214-28.

Waterhout, B., Othengrafen, F. and Sykes, O. (2013), "Neo-liberalization Processes and Spatial Planning in France, Germany, and the Netherlands: An Exploration", Planning Practice \& Research, Vol. 28 No. 1, pp. 141-59.

Yiftachel, O. (1989), "Towards a New Typology of Urban Planning Theories", Environment and Planning B: Planning and Design, Vol. 16, pp. 23-39. 
Table 1 - Leadership Theories

\begin{tabular}{|c|c|c|c|}
\hline \multicolumn{4}{|c|}{ Leadership Theories } \\
\hline $\begin{array}{l}\text { Leadership in an organization is } \\
\text { by: group, individuals, or none. }\end{array}$ & Definition - Leadership is ... & Leadership Processes & Sources \\
\hline \multicolumn{4}{|l|}{ None } \\
\hline Substitutes for leadership & $\begin{array}{l}\text { processes that organize, prioritize, and provide } \\
\text { structure. }\end{array}$ & $\begin{array}{l}\text { Rules, organizing charters, by-laws, moderated discussions, } \\
\text { brainstorming, round robin recording of ideas, voting, etc. }\end{array}$ & $\begin{array}{l}\text { (Avolio et al., } \\
2009 \text { ) }\end{array}$ \\
\hline \multicolumn{4}{|c|}{ 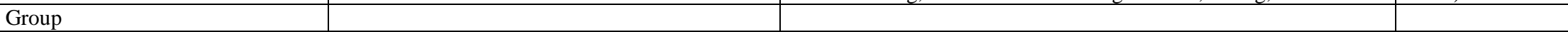 } \\
\hline Complexity leadership & $\begin{array}{l}\text { a dynamic network of interdependent agents } \\
\text { joined by history and common knowledge }\end{array}$ & $\begin{array}{l}\text { Exchange of information and knowledge, able to learn from } \\
\text { feedback and adapt, adept at dealing with non-technical } \\
\text { challenges, and highly interactive }\end{array}$ & $\begin{array}{l}\text { (Uhl-Bien et al., } \\
\text { 2007, Avolio et } \\
\text { al., 2009) }\end{array}$ \\
\hline Relational leadership & $\begin{array}{l}\text { made up of socially constructed relationships in } \\
\text { which change and order emerge and are } \\
\text { coordinated throughout the organization }\end{array}$ & $\begin{array}{l}\text { Sharing of responsibilities to keep the organization going through } \\
\text { interaction, social systems, social bonds (weak ties and strong } \\
\text { ties), sense-making, and structuration based on values, interests, } \\
\text { dialogue, and stories }\end{array}$ & $\begin{array}{l}\text { (Uhl-Bien, 2006, } \\
\text { Hosking, 2011) }\end{array}$ \\
\hline Shared/team leadership & $\begin{array}{l}\text { processes by which teams or small groups lead } \\
\text { themselves. }\end{array}$ & $\begin{array}{l}\text { Based in social interactions and sharing roles of monitoring } \\
\text { progress/effectiveness, staying on task, managing conflict and } \\
\text { collaborations, buffering, sharing information, modeling, and } \\
\text { networking along with mutual learning and shared understanding }\end{array}$ & $\begin{array}{l}\text { (Northhouse, } \\
2016, \text { Avolio et } \\
\text { al., 2009, Fletcher } \\
\text { and Käufer, 2003) }\end{array}$ \\
\hline \multicolumn{4}{|l|}{ Individuals } \\
\hline Followership and leadership & $\begin{array}{l}\text { dependent on followers who can make or break } \\
\text { a leader. }\end{array}$ & $\begin{array}{l}\text { The identities of followers intersect with the identities of leaders. } \\
\text { Followers can be passive receivers of direction or action-oriented } \\
\text { partners and leaders need to understand this dynamic and their } \\
\text { own self-development/awareness }\end{array}$ & $\begin{array}{l}\text { (Collinson, 2006, } \\
\text { Bligh, 2011) }\end{array}$ \\
\hline Servant leadership & $\begin{array}{l}\text { service to followers and concentrating on } \\
\text { followers' needs }\end{array}$ & $\begin{array}{l}\text { Service oriented, caring, listening, empathy, healing, community } \\
\text { building, shows appreciation for the service of others, role model, } \\
\text { uses a service commitment to inspire trust and commitment, and } \\
\text { orientation that the leader is a servant among servants }\end{array}$ & $\begin{array}{l}\text { (Northhouse, } \\
\text { 2016, van } \\
\text { Dierendonck and } \\
\text { Patterson, 2010, } \\
\text { Avolio et al., } \\
\text { 2009) }\end{array}$ \\
\hline Adaptive/empowering leadership & $\begin{array}{l}\text { mobilizing people to adapt, face change, and } \\
\text { tackle problems encouraging learning and self- } \\
\text { development. }\end{array}$ & $\begin{array}{l}\text { Encourages and allows followers to develop opportunity thinking, } \\
\text { teamwork, and self-leadership to address issues and } \\
\text { constructively confront change }\end{array}$ & $\begin{array}{l}\text { (Heifetz et al., } \\
\text { 2009, Pearce et } \\
\text { al., 2003) }\end{array}$ \\
\hline Spiritual leadership & $\begin{array}{l}\text { creating a sense of meaning in people's lives } \\
\text { bringing together body, mind, heart, and spirit } \\
\text { for a higher purpose }\end{array}$ & $\begin{array}{l}\text { Respect, compassion, growth, vision, inspiration, personal and } \\
\text { work values align around altruism and social responsibility }\end{array}$ & $\begin{array}{l}\text { (Avolio et al., } \\
\text { 2009, Fernando, } \\
\text { 2011) }\end{array}$ \\
\hline Authentic leadership & $\begin{array}{l}\text { using transparency, open communication, } \\
\text { acceptance of input from followers, and own } \\
\text { ethical behavior for decision making. }\end{array}$ & $\begin{array}{l}\text { Objective analysis of data, own behavior governed by morals, } \\
\text { self-awareness, and shows authentic self }\end{array}$ & $\begin{array}{l}\text { (Avolio et al., } \\
\text { 2009) }\end{array}$ \\
\hline
\end{tabular}




\begin{tabular}{|c|c|c|c|}
\hline \multicolumn{4}{|c|}{ Leadership Theories } \\
\hline $\begin{array}{l}\text { Leadership in an organization is } \\
\text { by: group, individuals, or none. }\end{array}$ & Definition - Leadership is ... & Leadership Processes & Sources \\
\hline $\begin{array}{l}\text { Transformational/charismatic } \\
\text { leadership }\end{array}$ & $\begin{array}{l}\text { connecting with the motives of followers and } \\
\text { assesses their needs on the way to } \\
\text { accomplishing long-term goals resulting in } \\
\text { followers doing more than they thought } \\
\text { possible. }\end{array}$ & $\begin{array}{l}\text { Transforms people through values and goals, makes connections } \\
\text { to followers on a human level, and unleashes the full potential of } \\
\text { followers to do more }\end{array}$ & $\begin{array}{l}\text { (Northhouse, } \\
\text { 2016) }\end{array}$ \\
\hline Leader-member exchange & $\begin{array}{l}\text { connecting with each individual follower at } \\
\text { different levels seeking mutual obligations and } \\
\text { trust resulting in an in-group and an out-group } \\
\text { where some people in the organization give and } \\
\text { get more from the leader and others stick to } \\
\text { contractual exchanges }\end{array}$ & $\begin{array}{l}\text { Mutual dependence, respect, communication and trust, } \\
\text { interactions for some go beyond job descriptions but not for } \\
\text { others }\end{array}$ & $\begin{array}{l}\text { (Northhouse, } \\
\text { 2016, Avolio et } \\
\text { al., 2009, Anand } \\
\text { et al., 2011) }\end{array}$ \\
\hline Transactional leadership & using rewards to condition performance. & Rewards for followers who perform their work well & $\begin{array}{l}\text { (Pearce et al., } \\
2003 \text { ) }\end{array}$ \\
\hline Directive leadership & $\begin{array}{l}\text { using authority and coercion to direct follower } \\
\text { behavior. }\end{array}$ & $\begin{array}{l}\text { Assigns tasks, organizes activities, defines how to do the work, } \\
\text { clear communication channels, looks for goal success, directs } \\
\text { followers, coordinates activities }\end{array}$ & $\begin{array}{l}\text { (Pearce et al., } \\
\text { 2003) }\end{array}$ \\
\hline
\end{tabular}


Table 2 - Planning Theories

\begin{tabular}{|c|c|c|}
\hline Planning Theory & Definition of Planning Process & Sources \\
\hline Systems & $\begin{array}{l}\text { Through models seeking to understand the complexity of places, cities, and regions } \\
\text { as multi-purpose and interconnected with dynamic components that can self-organize } \\
\text { and adapt. }\end{array}$ & $\begin{array}{l}\text { (Brown, 2014, Allmendinger, 2009, } \\
\text { Allmendinger, 2017) }\end{array}$ \\
\hline Rational & $\begin{array}{l}\text { Technical, value-neutral course of action proceeding through the identification of } \\
\text { goals, alternatives, consequences of pursuing those alternatives, making a choice } \\
\text { based on consequences, implementing the choice, and evaluating the choice. }\end{array}$ & $\begin{array}{l}\text { (Brooks, 2002, Black, 1990, } \\
\text { Allmendinger, 2009, Allmendinger, } \\
\text { 2017) }\end{array}$ \\
\hline Incrementalism & $\begin{array}{l}\text { Practical decisions are made by evaluating only a few choices or alternatives, } \\
\text { analyzing and evaluating as implementation occurs, small changes address present } \\
\text { problems which are pursued over seeking an ideal future. }\end{array}$ & $\begin{array}{l}\text { (Lindblom, 1959/1987, Brooks, } \\
\text { 2002, Allmendinger, 2009, } \\
\text { Allmendinger, 2017) }\end{array}$ \\
\hline Mixed Scanning & $\begin{array}{l}\text { Combined rational in incremental processes by pursuing rationality when there is } \\
\text { time and resources or when setting policy but using incremental tactics at most other } \\
\text { times. }\end{array}$ & $\begin{array}{l}\text { (Brooks, 2002, Etzioni, 1967, } \\
\text { Allmendinger, 2009, Allmendinger, } \\
\text { 2017) }\end{array}$ \\
\hline Transactive & $\begin{array}{l}\text { Knowledge is connected to action and change occurs through a chain of } \\
\text { interpersonal relations with experts providing analysis and citizens contributing on- } \\
\text { the-ground knowledge that builds on authentic relationships, mutual obligations, } \\
\text { mutual learning, and common trust. }\end{array}$ & $\begin{array}{l}\text { (Whittemore, 2014, Friedmann, } \\
\text { 1973, Allmendinger, 2009, } \\
\text { Allmendinger, 2017) }\end{array}$ \\
\hline Advocacy & $\begin{array}{l}\text { Values guide course of action bringing rational planning to non-experts and } \\
\text { underrepresented groups to create their own plans to compete with establishment } \\
\text { plans, also includes seeking equity through redistribution of resources. }\end{array}$ & $\begin{array}{l}\text { (Davidoff, 1965/2003, Davidoff and } \\
\text { Reiner, 1962, Brooks, 2002, } \\
\text { Susskind et al., 2003, Allmendinger, } \\
\text { 2009, Allmendinger, 2017) }\end{array}$ \\
\hline Progressive & $\begin{array}{l}\text { Attention to power dynamics, communication, listening, and Marxian critiques along } \\
\text { with valuing equality, social and environmental justice spur action in drawing on } \\
\text { groups outside of government and social movements to exert political pressure on } \\
\text { elected officials. }\end{array}$ & $\begin{array}{l}\text { (Forester, 1989, Krumholz and } \\
\text { Forester, 1990, Forsythe, 1999, } \\
\text { Allmendinger, 2017) }\end{array}$ \\
\hline Communicative & $\begin{array}{l}\text { Awareness of how information represents power, values, and collective sense- } \\
\text { making and allowing for the equal dissemination of information to fairly compete for } \\
\text { attention and action. }\end{array}$ & $\begin{array}{l}\text { (Brooks, 2002, Healey, 1996/2003, } \\
\text { Susskind et al., 2003, Allmendinger, } \\
\text { 2001, Allmendinger, 2009, } \\
\text { Allmendinger, 2017) }\end{array}$ \\
\hline Collaborative & $\begin{array}{l}\text { Relies on the creation of networks of stakeholders to facilitate the sharing of } \\
\text { information and resources, along with mediations, negotiations, consensus building, } \\
\text { and the construction of social capital. }\end{array}$ & $\begin{array}{l}\text { (Brooks, 2002, Innes, 1996, Innes, } \\
\text { 1997, Allmendinger, 2017) }\end{array}$ \\
\hline
\end{tabular}




\begin{tabular}{|l|l|l|}
\hline Agonism & $\begin{array}{l}\text { Sees conflict not as irreconcilable views of enemies but as disagreements between } \\
\text { adversaries who can communicate and find solutions that all agree to or at least } \\
\text { continue to respect each other and work together in the future. }\end{array}$ & $\begin{array}{l}\text { (Allmendinger, 2001, Mouffe, 2000, } \\
\text { Pløger, 2004) }\end{array}$ \\
\hline
\end{tabular}


Table 3 Comparing Planning Office of the Future Report and Leadership Theories

\begin{tabular}{|l|c|c|}
\hline \multicolumn{1}{|c|}{ Planning Processes } & Leadership Theories & Number of Leaders \\
\hline Get close to decision-makers & Relational & Group \\
\hline Exercise different kinds of community leadership & -- & \\
\hline Address emerging issues and trends & Complexity & Group \\
\hline Define the planning agency's purpose and scope & Substitutes & None \\
\hline Develop informal networks & Complexity & Group \\
\hline Educate elected officials and citizens & Complexity & Group \\
\hline Build consensus with other agencies & Complexity & Group \\
\hline Communicate through various news media & Complexity & Group \\
\hline Identify and assess trends as they emerge & Complexity & Group \\
\hline Educate the community about issues and trends & Complexity & Group \\
\hline
\end{tabular}


Table 4 Comparing Planning Theories and Leadership Theories

\begin{tabular}{|l|c|c|c|}
\hline \multicolumn{1}{|c|}{$\begin{array}{c}\text { Planning } \\
\text { Theories }\end{array}$} & Keyword/Concept Matches & Leadership Theories & Number of Leaders \\
\hline Systems & complexity, interconnected, self-organize, \\
adapt & course of action & Complexity & Group \\
\hline Rational & evaluate, adapt & Substitutes & None \\
\hline Incrementalism & evaluate, adapt & Adaptive/ Empowering & Individual \\
\hline Mixed Scanning & Adaptive/Empowering & Group, Group, \\
Transactive & learning/obligations, trust & $\begin{array}{c}\text { Complexity, Relational, } \\
\text { Adaptive/Empowering }\end{array}$ & Individual \\
\hline Advocacy & taking expertise to underrepresented groups & Adaptive/Empowering & Individual, \\
\hline Progressive & communication, listening, social movements & Adaptive/Empowering, Authentic & Group \\
\hline Communicative & information, collective sense-making & Complexity & Group \\
\hline Collaborative & networks, social capital & Relational & None \\
\hline Agonism & constructive view of conflict & Substitutes & \\
\hline
\end{tabular}


Table 5 Comparing American Institute of Certified Planners Code of Ethics, United States and Leadership Theories

\begin{tabular}{|c|c|c|c|}
\hline \multicolumn{4}{|c|}{ Code of Ethics from the American Institute of Certified Planners, United States (American Planning Association, 2017) } \\
\hline What do planners do? & Common Themes & Leadership Theories & $\begin{array}{l}\text { Number of } \\
\text { Leaders }\end{array}$ \\
\hline Serve the public interest & service & Servant & Individual \\
\hline Continuous and open debate & sense-making & Adaptive/Empowering & Individual \\
\hline Conscious of the rights of others & respect, social responsibility & Spiritual & Individual \\
\hline $\begin{array}{l}\text { Concern for the long-range } \\
\text { consequences of present actions }\end{array}$ & adapt, vision & $\begin{array}{l}\text { Adaptive/Empowering, } \\
\text { Spiritual }\end{array}$ & $\begin{array}{l}\text { Individual, } \\
\text { Individual }\end{array}$ \\
\hline $\begin{array}{l}\text { Attention to the interrelatedness of } \\
\text { decisions }\end{array}$ & dynamic network & Complexity & Group \\
\hline $\begin{array}{l}\text { Provide timely, adequate, clear, and } \\
\text { accurate information on planning issues } \\
\text { to all affected persons and to } \\
\text { governmental decision makers. }\end{array}$ & interactive & Complexity & Group \\
\hline $\begin{array}{l}\text { Give people the opportunity to have a } \\
\text { meaningful impact on the development } \\
\text { of plans and programs that may affect } \\
\text { them. Participation should be broad } \\
\text { enough to include those who lack formal } \\
\text { organization or influence. }\end{array}$ & $\begin{array}{l}\text { self-leadership, develop } \\
\text { teamwork }\end{array}$ & Adaptive/Empowering & Individual \\
\hline $\begin{array}{l}\text { Seek social justice by working to } \\
\text { expand choice and opportunity for all } \\
\text { persons, recognizing a special } \\
\text { responsibility to plan for the needs of } \\
\text { the disadvantaged and to promote racial } \\
\text { and economic integration. We shall urge } \\
\text { the alteration of policies, institutions, } \\
\text { and decisions that oppose such needs. }\end{array}$ & $\begin{array}{l}\text { social responsibility, } \\
\text { transforms people }\end{array}$ & $\begin{array}{c}\text { Spiritual, } \\
\text { Adaptive/Empowering }\end{array}$ & $\begin{array}{l}\text { Individual, } \\
\text { Individual }\end{array}$ \\
\hline $\begin{array}{l}\text { Promote excellence of design and } \\
\text { endeavor to conserve and preserve the }\end{array}$ & -- & -- & -- \\
\hline
\end{tabular}




\begin{tabular}{|c|c|c|c|}
\hline \multicolumn{4}{|c|}{ Code of Ethics from the American Institute of Certified Planners, United States (American Planning Association, 2017) } \\
\hline What do planners do? & Common Themes & Leadership Theories & $\begin{array}{c}\text { Number of } \\
\text { Leaders }\end{array}$ \\
\hline \multicolumn{4}{|l|}{$\begin{array}{l}\text { integrity and heritage of the natural and } \\
\text { built environment. }\end{array}$} \\
\hline $\begin{array}{l}\text { Deal fairly with all participants in the } \\
\text { planning process. }\end{array}$ & $\begin{array}{l}\text { transparency, open } \\
\text { communication }\end{array}$ & Authentic & Individual \\
\hline $\begin{array}{l}\text { Exercise independent professional } \\
\text { judgment on behalf of our clients and } \\
\text { employers. }\end{array}$ & objective analysis & Authentic & Individual \\
\hline $\begin{array}{l}\text { Accept the decisions of our client or } \\
\text { employer concerning the objectives and } \\
\text { nature of the professional services we } \\
\text { perform unless the course of action is } \\
\text { illegal or plainly inconsistent with our } \\
\text { primary obligation to the public interest. }\end{array}$ & leader and followers intersect & Followership & Individual \\
\hline $\begin{array}{l}\text { Avoid a conflict of interest or even the } \\
\text { appearance of a conflict of interest in } \\
\text { accepting assignments from clients or } \\
\text { employers. }\end{array}$ & trust, transparency & Servant, Authentic & $\begin{array}{l}\text { Individual, } \\
\text { Individual }\end{array}$ \\
\hline $\begin{array}{l}\text { Improving knowledge and techniques, } \\
\text { making work relevant to solutions of } \\
\text { community problems, and increasing } \\
\text { public understanding of planning } \\
\text { activities. }\end{array}$ & $\begin{array}{c}\text { interactive, education, mutual } \\
\text { learning }\end{array}$ & $\begin{array}{c}\text { Complexity, } \\
\text { Adaptive/Empowering }\end{array}$ & Group, Individual \\
\hline $\begin{array}{l}\text { Shall examine the applicability of } \\
\text { planning theories, methods, research and } \\
\text { practice and standards to the facts and } \\
\text { analysis of each particular situation and } \\
\text { shall not accept the applicability of a } \\
\text { customary solution without first } \\
\text { establishing its appropriateness to the } \\
\text { situation. }\end{array}$ & objective analysis & Authentic & Individual \\
\hline
\end{tabular}




\begin{tabular}{|c|c|c|c|}
\hline \multicolumn{4}{|c|}{ Code of Ethics from the American Institute of Certified Planners, United States (American Planning Association, 2017) } \\
\hline What do planners do? & Common Themes & Leadership Theories & $\begin{array}{l}\text { Number of } \\
\text { Leaders }\end{array}$ \\
\hline $\begin{array}{l}\text { Systematically and critically analyze } \\
\text { ethical issues in the practice of planning }\end{array}$ & own ethical behavior & Authentic & Individual \\
\hline $\begin{array}{l}\text { Contribute time and effort to groups } \\
\text { lacking in adequate planning resources } \\
\text { and to voluntary professional activities. }\end{array}$ & service & Servant & Individual \\
\hline $\begin{array}{l}\text { Shall not, as public officials or } \\
\text { employees, engage in private } \\
\text { communications with planning process } \\
\text { participants if the discussions relate to a } \\
\text { matter over which we have authority to } \\
\text { make a binding, final determination if } \\
\text { such private communications are } \\
\text { prohibited by law or by agency rules, } \\
\text { procedures, or custom. }\end{array}$ & laws, rules & Followership & Individual \\
\hline $\begin{array}{l}\text { Shall not use the power of any office to } \\
\text { seek or obtain a special advantage that is } \\
\text { not a matter of public knowledge or is } \\
\text { not in the public interest. }\end{array}$ & trust & Servant & Individual \\
\hline $\begin{array}{l}\text { Shall not direct or coerce other } \\
\text { professionals to make analyses or reach } \\
\text { findings not supported by available } \\
\text { evidence. }\end{array}$ & $\begin{array}{l}\text { interactive, interdependent } \\
\text { agents }\end{array}$ & Complexity & Group \\
\hline $\begin{array}{l}\text { Shall not unlawfully discriminate } \\
\text { against another person. }\end{array}$ & law & Followership & Individual \\
\hline
\end{tabular}


Table 6 Comparing Royal Town Planning Institute Code of Ethics, United Kingdom and Leadership Theories

\begin{tabular}{|c|c|c|c|}
\hline \multicolumn{4}{|c|}{$\begin{array}{c}\text { Code of Ethics from the Royal Town Planning Institute, United Kingdom (Royal Town Planning } \\
\text { Institute, 2017) }\end{array}$} \\
\hline What do planners do? & $\begin{array}{l}\text { Common } \\
\text { Themes }\end{array}$ & Leadership Theories & $\begin{array}{l}\text { Number of } \\
\text { Leaders }\end{array}$ \\
\hline $\begin{array}{l}\text { Conduct themselves in a way that inspires } \\
\text { trust and confidence in the profession }\end{array}$ & trust & Servant & Individual \\
\hline $\begin{array}{l}\text { Act with honesty and integrity throughout } \\
\text { their career. }\end{array}$ & $\begin{array}{l}\text { transparency, } \\
\text { ethical }\end{array}$ & Authentic & Individual \\
\hline $\begin{array}{l}\text { Take all reasonable steps to ensure that } \\
\text { their private, personal, political and } \\
\text { financial interests do not conflict with their } \\
\text { professional duties. }\end{array}$ & $\begin{array}{c}\text { trust, } \\
\text { transparency }\end{array}$ & Servant, Authentic & $\begin{array}{l}\text { Individual, } \\
\text { Individual }\end{array}$ \\
\hline $\begin{array}{l}\text { Must not disclose or use to the advantage } \\
\text { of themselves, their employers or clients } \\
\text { information acquired in confidence in the } \\
\text { course of their work. }\end{array}$ & trust & Servant & Individual \\
\hline $\begin{array}{l}\text { Must exercise fearlessly and impartially } \\
\text { their independent professional judgement } \\
\text { to the best of their skill and understanding. }\end{array}$ & $\begin{array}{l}\text { objective } \\
\text { analysis }\end{array}$ & Authentic & Individual \\
\hline $\begin{array}{l}\text { Must not discriminate on grounds } \\
\text { including but not limited to race, } \\
\text { nationality, gender, sexual orientation, } \\
\text { religion, disability or age. }\end{array}$ & $\begin{array}{c}\text { social } \\
\text { responsibility }\end{array}$ & Spiritual & Individual \\
\hline $\begin{array}{l}\text { Must seek to eliminate discrimination by } \\
\text { others and promote equality of opportunity } \\
\text { throughout their professional activities. }\end{array}$ & $\begin{array}{l}\text { social } \\
\text { responsibility, } \\
\text { transforms } \\
\text { people }\end{array}$ & $\begin{array}{c}\text { Spiritual, } \\
\text { Adaptive/Empowering }\end{array}$ & $\begin{array}{l}\text { Individual, } \\
\text { Individual }\end{array}$ \\
\hline
\end{tabular}


Table 7 Comparing New Zealand Planning Institute Code of Ethics, New Zealand and Leadership Theories

\begin{tabular}{|c|c|c|c|}
\hline \multicolumn{4}{|c|}{$\begin{array}{c}\text { Code of Ethics from the New Zealand Planning Institute, New Zealand (New Zealand Planning } \\
\text { Institute, 2017) }\end{array}$} \\
\hline What do planners do? & Common Themes & Leadership Theories & $\begin{array}{c}\text { Number of } \\
\text { Leaders }\end{array}$ \\
\hline $\begin{array}{l}\text { Shall maintain an appropriate professional } \\
\text { awareness of issues related to the Treaty } \\
\text { of Waitangi and to the needs and interests } \\
\text { of Tangata Whenua. }\end{array}$ & $\begin{array}{c}\text { joined by history, } \\
\text { law }\end{array}$ & $\begin{array}{l}\text { Complexity, } \\
\text { Followership }\end{array}$ & $\begin{array}{c}\text { Many, } \\
\text { Individual }\end{array}$ \\
\hline $\begin{array}{l}\text { Shall, subject to respecting a client's or } \\
\text { employer's right of confidentiality, } \\
\text { endeavor to ensure that full, clear and } \\
\text { accurate information is available }\end{array}$ & trust, transparency & Servant, Authentic & $\begin{array}{l}\text { Individual, } \\
\text { Individual }\end{array}$ \\
\hline $\begin{array}{l}\text { Are meaningful opportunities for public } \\
\text { input and participation. }\end{array}$ & $\begin{array}{l}\text { self-leadership, } \\
\text { develop teamwork }\end{array}$ & Adaptive/Empowering & Individual \\
\hline $\begin{array}{l}\text { Ensure that special attention is paid to the } \\
\text { inter-relatedness of decisions and the } \\
\text { environmental, social and economic } \\
\text { consequences of planning actions }\end{array}$ & dynamic network & Complexity & Group \\
\hline $\begin{array}{l}\text { Recognise the need to maintain and } \\
\text { promote high environmental standards } \\
\text { and outcomes. }\end{array}$ & -- & -- & -- \\
\hline $\begin{array}{l}\text { Carry out all professional work with } \\
\text { integrity, and in a spirit of fairness, } \\
\text { fidelity and objectivity }\end{array}$ & $\begin{array}{l}\text { transparency, open } \\
\text { communication }\end{array}$ & Authentic & Individual \\
\hline $\begin{array}{l}\text { Shall not make any misleading claims, or } \\
\text { attempt to influence any decisions by } \\
\text { improper means. }\end{array}$ & trust, transparency & Servant, Authentic & $\begin{array}{l}\text { Individual, } \\
\text { Individual }\end{array}$ \\
\hline $\begin{array}{l}\text { Shall strive to ascertain the appropriate } \\
\text { factual situation, and maintain unbiased } \\
\text { and object judgement, and shall not give }\end{array}$ & objective analysis & Authentic & Individual \\
\hline
\end{tabular}




\begin{tabular}{|c|c|c|c|}
\hline \multicolumn{3}{|c|}{ Code of Ethics from the New Zealand Planning Institute, New Zealand (New Zealand Planning } \\
Institute, 2017) & Common Themes & Leadership Theories & $\begin{array}{c}\text { Number of } \\
\text { Leaders }\end{array}$ \\
\hline What do planners do? & Commen & \\
\hline $\begin{array}{l}\text { professional advice or evidence which is } \\
\text { other than their true professional opinion. }\end{array}$ & & \\
\hline
\end{tabular}


Table 8 Comparing South African Planning Institute Code of Conduct, South Africa and Leadership Theories

\begin{tabular}{|l|c|c|c|}
\hline \multicolumn{2}{|c|}{ Code of Conduct from the South African Planning Institute, South Africa (South African } \\
Planning Institute, 2017)
\end{tabular}




\begin{tabular}{|c|c|c|c|}
\hline \multicolumn{4}{|c|}{$\begin{array}{c}\text { Code of Conduct from the South African Planning Institute, South Africa (South African } \\
\text { Planning Institute, 2017) }\end{array}$} \\
\hline What do planners do? & $\begin{array}{l}\text { Common } \\
\text { Themes }\end{array}$ & Leadership Theories & $\begin{array}{c}\text { Number of } \\
\text { Leaders }\end{array}$ \\
\hline \multicolumn{4}{|l|}{$\begin{array}{l}\text { beneficiaries, affected parties and / or the } \\
\text { public at large. }\end{array}$} \\
\hline $\begin{array}{l}\text { Respect the rights of others and in } \\
\text { particular the rights of the public. }\end{array}$ & $\begin{array}{l}\text { respect, social } \\
\text { responsibility }\end{array}$ & Spiritual & Individual \\
\hline $\begin{array}{l}\text { Shall approach their responsibilities in a } \\
\text { way that seeks to promote the profession } \\
\text { through capacity-building, and to promote } \\
\text { informed decision-making where relevant } \\
\text { with respect to affected parties. }\end{array}$ & $\begin{array}{l}\text { transforms } \\
\text { people, skills of } \\
\text { followers }\end{array}$ & $\begin{array}{l}\text { Adaptive/Empowering, } \\
\text { Followership }\end{array}$ & $\begin{array}{l}\text { Individual, } \\
\text { Individual }\end{array}$ \\
\hline $\begin{array}{l}\text { All persons have the right to a healthy and } \\
\text { ecologically balanced environment. In } \\
\text { order to secure this right, members shall } \\
\text { strive to foster and promote balanced and } \\
\text { appropriate social and economic growth } \\
\text { and development of the country and its } \\
\text { people. }\end{array}$ & -- & -- & -- \\
\hline $\begin{array}{l}\text { Strive to promote the rational use of } \\
\text { natural resources with regard to local, } \\
\text { regional and national planning in the } \\
\text { maintenance or creation of both balanced } \\
\text { and sustainable ecological and biological } \\
\text { areas. }\end{array}$ & -- & -- & -- \\
\hline $\begin{array}{l}\text { Be familiar with all the relevant } \\
\text { legislation that relates both directly and } \\
\text { indirectly to planning and the } \\
\text { environment. }\end{array}$ & law & Followership & Individual \\
\hline $\begin{array}{l}\text { Subscribe to, honest, fair and just } \\
\text { governance measures in all their affairs } \\
\text { and activities that promote the meaningful }\end{array}$ & $\begin{array}{l}\text { transparency, } \\
\text { ethical }\end{array}$ & Authentic & Individual \\
\hline
\end{tabular}




\begin{tabular}{|c|c|c|c|}
\hline \multicolumn{3}{|c|}{ Code of Conduct from the South African Planning Institute, South Africa (South African } \\
Planning Institute, 2017)
\end{tabular}


Table 9 Comparing European Council of Spatial Planners / Conseil Européen des Urbanistes Charter of Professional Conduct and Leadership Theories

\begin{tabular}{|l|c|c|c|}
\hline \multicolumn{3}{|c|}{$\begin{array}{c}\text { Charter of Professional Conduct from the European Council of Spatial Planners / Conseil } \\
\text { Européen des Urbanistes (European Council of Spatial Planners / Conseil Européen des } \\
\text { Urbanistes, 2017a) }\end{array}$} \\
\hline \multicolumn{1}{|c|}{ What do planners do? } & Common Themes & Leadership Theories & $\begin{array}{c}\text { Number of } \\
\text { Leaders }\end{array}$ \\
\hline $\begin{array}{l}\text { Shall act with integrity and } \\
\text { honesty with the interests of the } \\
\text { community being their } \\
\text { paramount consideration }\end{array}$ & transparency, ethical & Authentic & Individual \\
\hline $\begin{array}{l}\text { Exercise their independent } \\
\text { professional judgement to the } \\
\text { best of their skill and } \\
\text { understanding }\end{array}$ & objective analysis & Authentic & Individual \\
\hline $\begin{array}{l}\text { Not discriminate on the grounds } \\
\text { of race, sex, sexual orientation, } \\
\text { creed, religion, disability or age }\end{array}$ & social responsibility & Spiritual & Individual \\
\hline $\begin{array}{l}\text { Shall seek to promote equality } \\
\text { of opportunity }\end{array}$ & social responsibility, \\
transforms people & Adaptive/Empowering & Individual \\
\hline $\begin{array}{l}\text { Respect other related } \\
\text { professions and shall collaborate } \\
\text { with them and seek their } \\
\text { expertise whenever appropriate } \\
\text { to the nature of the task. }\end{array}$ & dynamic network & Complexity & Group \\
\hline
\end{tabular}


Table 10 Comparing the Institute of Town Planners, Sri Lanka Code of Conduct, Sri Lanka and Leadership Theories

\begin{tabular}{|l|c|c|c|}
\hline \multicolumn{1}{|c|}{ Code of Conduct from the Institute of Town Planners, Sri Lanka (Institute of Town Planners Sri Lanka, 2017) } \\
\hline \multicolumn{1}{|c|}{$\begin{array}{c}\text { Wommon } \\
\text { Themes }\end{array}$} & $\begin{array}{c}\text { Leadership Theories } \\
\text { Number of } \\
\text { position in which his interest is in } \\
\text { conflict with his professional duty. }\end{array}$ & $\begin{array}{c}\text { trust, } \\
\text { transparency }\end{array}$ & $\begin{array}{c}\text { Servant, Authentic } \\
\text { Individuidual, }\end{array}$ \\
\hline $\begin{array}{l}\text { Shall seek to eliminate discrimination on } \\
\text { the ground of race, sex, creed and } \\
\text { religion and in particular shall seek to } \\
\text { promote equality of opportunity between } \\
\text { people of different groups and good race } \\
\text { relations. }\end{array}$ & $\begin{array}{c}\text { social } \\
\text { responsibility, } \\
\text { transform people }\end{array}$ & $\begin{array}{c}\text { Spiritual, } \\
\text { Adaptive/Empowering }\end{array}$ & $\begin{array}{c}\text { Individual, } \\
\text { Individual }\end{array}$ \\
\hline
\end{tabular}


Table 11 Comparing the Forum for Municipal Planning Forum for Kommunal Planlegging, Ethical Platform, Norway and Leadership Theories

\begin{tabular}{|c|c|c|c|}
\hline \multicolumn{4}{|c|}{$\begin{array}{l}\text { Ethical Platform from Forum for Municipal Planning } \\
\text { Forum for Kommunal Planlegging, Norway (Forum for Kommunal Planlegging, 2017) }\end{array}$} \\
\hline What do planners do? & $\begin{array}{l}\text { Common } \\
\text { Themes }\end{array}$ & Leadership Theories & $\begin{array}{l}\text { Number of } \\
\text { Leaders }\end{array}$ \\
\hline $\begin{array}{l}\text { Promote sustainable development to the best for individuals, society and } \\
\text { future generations, based on transparency, predictability and participation } \\
\text { for all private and public parties involved. }\end{array}$ & $\begin{array}{l}\text { Adapt, } \\
\text { interactive, } \\
\text { transparent, trust, } \\
\text { predictability }\end{array}$ & $\begin{array}{l}\text { Servant, Authentic, } \\
\text { Complexity }\end{array}$ & $\begin{array}{l}\text { Individual, } \\
\text { Individual, } \\
\text { Group }\end{array}$ \\
\hline $\begin{array}{l}\text { Conscious their social responsibility, and encourage that it is expressed } \\
\text { through action. }\end{array}$ & $\begin{array}{c}\text { social } \\
\text { responsibility }\end{array}$ & Spiritual & Individual \\
\hline $\begin{array}{l}\text { Based on the Norwegian democracy's fundamental principles of equality, } \\
\text { openness, rule of law and rights to participation. }\end{array}$ & $\begin{array}{l}\text { Law, } \\
\text { participation, } \\
\text { transparency }\end{array}$ & $\begin{array}{l}\text { Followership, Authentic, } \\
\text { Adaptive/Empowering }\end{array}$ & $\begin{array}{l}\text { Individual, } \\
\text { Individual, } \\
\text { Individual }\end{array}$ \\
\hline Based on best accessible and updated knowledge & Knowledge & Complexity & Group \\
\hline $\begin{array}{l}\text { Show respect to the elected officials' tasks and roles, within the framework } \\
\text { of the planner's own professional integrity and the mission of planning. }\end{array}$ & Rules, laws & Followership & Individual \\
\hline $\begin{array}{l}\text { Shall assist in making clear the range of opportunities within the } \\
\text { framework of national policy, law and regulations, and accessible } \\
\text { resources }\end{array}$ & Service, laws & Servant, Followership & $\begin{array}{l}\text { Individual, } \\
\text { Individual }\end{array}$ \\
\hline Separate the person from the problem and build trust between parties. & Objective, trust & Authentic & Individual \\
\hline $\begin{array}{l}\text { Meet everyone with openness, understanding and guidance, and facilitate } \\
\text { good planning processes that promote involvement and participation. }\end{array}$ & $\begin{array}{l}\text { Facilitate, open, } \\
\text { involvement }\end{array}$ & $\begin{array}{c}\text { Complexity, } \\
\text { Adaptive/Empowering }\end{array}$ & $\begin{array}{c}\text { Group, } \\
\text { Individual }\end{array}$ \\
\hline $\begin{array}{l}\text { Assist disadvantaged groups participating and advocate that no groups or } \\
\text { interests are discriminated. }\end{array}$ & advocacy & Spiritual & Individual \\
\hline $\begin{array}{l}\text { Shall demonstrate openness and respect to other professional methods and } \\
\text { contributions, and commit to innovation and holistic solutions through } \\
\text { cooperation with fellow planners and other professional }\end{array}$ & $\begin{array}{l}\text { Dynamic } \\
\text { networks, } \\
\text { interdependent } \\
\text { agents }\end{array}$ & Complexity & Group \\
\hline
\end{tabular}


Table 12: Planners' Leadership Comfort Zone (C's) and Uncomfortable (Gray) Zone

\begin{tabular}{|c|c|c|c|c|c|c|c|c|c|c|c|c|c|c|}
\hline & \multicolumn{14}{|c|}{ Leadership Theories } \\
\hline & None & & Group & & & & & & & Individ & & & & \\
\hline $\begin{array}{l}\text { Sources of } \\
\text { Planning } \\
\text { Processes }\end{array}$ & Substitutes & Complexity & Relational & $\begin{array}{l}\text { Shared } \\
\text { /team }\end{array}$ & $\begin{array}{l}\text { Place- } \\
\text { based }\end{array}$ & Followership & Servant & $\begin{array}{l}\text { Adaptive/ } \\
\text { empowering }\end{array}$ & Spiritual & Authentic & $\begin{array}{l}\text { Transformation } \\
\text { /charismatic }\end{array}$ & $\begin{array}{l}\text { Leader- } \\
\text { member } \\
\text { exchange }\end{array}$ & Transactional & Directive \\
\hline $\begin{array}{l}\text { Planning } \\
\text { Office of } \\
\text { the Future } \\
\text { Report }\end{array}$ & $\mathrm{C}$ & $\mathrm{C}$ & C & & & & & & & & & & & \\
\hline $\begin{array}{l}\text { Planning } \\
\text { Theories }\end{array}$ & $\mathrm{C}$ & $\mathrm{C}$ & $\mathrm{C}$ & & & & & $\mathrm{C}$ & & $\mathrm{C}$ & & & & \\
\hline $\begin{array}{l}\text { American } \\
\text { Institute } \\
\text { of } \\
\text { Certified } \\
\text { Planners } \\
\text { (U.S.) } \\
\end{array}$ & & $\mathrm{C}$ & & & $\mathrm{C}$ & $\mathrm{C}$ & $\mathrm{C}$ & $\mathrm{C}$ & $\mathrm{C}$ & $\mathrm{C}$ & & & & \\
\hline $\begin{array}{l}\text { Royal } \\
\text { Town } \\
\text { Planning } \\
\text { Institute }\end{array}$ & & & & & & & $\mathrm{C}$ & $\mathrm{C}$ & $\mathrm{C}$ & $\mathrm{C}$ & & & & \\
\hline $\begin{array}{l}\text { New } \\
\text { Zealand } \\
\text { Planning } \\
\text { Institute }\end{array}$ & & $\mathrm{C}$ & & & $\mathrm{C}$ & $\mathrm{C}$ & $\mathrm{C}$ & $\mathrm{C}$ & & $\mathrm{C}$ & & & & \\
\hline $\begin{array}{l}\text { South } \\
\text { African } \\
\text { Planning } \\
\text { Institute }\end{array}$ & & $\mathrm{C}$ & & & $\mathrm{C}$ & $\mathrm{C}$ & $\mathrm{C}$ & $\mathrm{C}$ & $\mathrm{C}$ & $\mathrm{C}$ & & & & \\
\hline $\begin{array}{l}\text { European } \\
\text { Council of } \\
\text { Spatial } \\
\text { Planners / } \\
\text { Conseil } \\
\text { Européen } \\
\text { des } \\
\text { Urbanistes } \\
\end{array}$ & & $\mathrm{C}$ & & & & & & $\mathrm{C}$ & $\mathrm{C}$ & C & & & & \\
\hline $\begin{array}{l}\text { Institute } \\
\text { of Town } \\
\text { Planners, } \\
\text { Sri Lanka } \\
\end{array}$ & & & & & & & $\mathrm{C}$ & $\mathrm{C}$ & $\mathrm{C}$ & $\mathrm{C}$ & & & & \\
\hline $\begin{array}{l}\text { Forum for } \\
\text { Municipal } \\
\text { Planning, } \\
\text { Norway }\end{array}$ & & $\mathrm{C}$ & & & & $\mathrm{C}$ & $\mathrm{C}$ & $\mathrm{C}$ & $\mathrm{C}$ & $\mathrm{C}$ & & & & \\
\hline
\end{tabular}


